\title{
The electric motor in Portugal: technological progress and industrialization
}

\author{
Ana Cardoso de MATOS ${ }^{1}$, Maria da Luz SAMPAIO ${ }^{2}$ \\ (1) CIDEHUS - University of Évora - Évora, Portugal \\ anacmatos@mail.telepac.pt \\ (2) CIDEHUS - University of Évora - Évora, Portugal / IHC - Faculdade de \\ Ciências Sociais e Humanas - Universidade NOVA de Lisboa, Portugal \\ mluzsampaio@gmail.com
}

\begin{abstract}
The introduction of the electric motor in Portugal is due to foreigner companies such as Siemens, AEG, ASEA, and ACEC. They were important levers to move the electrical sector, the electricity network, and the technological progress. Portugal only started the manufacture electric motors in large quantities in 1946 when ACEC, EFA and CUF united to set up to develop a business project and the introduction of the electric motor in Portugal has common aspects with others European countries.

In this paper we add different views and through the analysis of photograph we describe the entry of the electric motor into the factory and the impact of electrical motor in the manufacturing space, which allowed, not only, to rationalize the flows between the machine but also and operating a new circuit between the different machines or operations.
\end{abstract}

Keywords: motor, factory, electricity, technological progress

\section{The progress of electrical Network of Portugal}

In Portugal, the introduction of electricity dates back to the end of the 19th century. The transference of technology was possible due to the foreign banks capital, electro-technical engineers, and entrepreneurs. This became evident in the case study of CRGE- Companhia Reunidas de Gás e Electricidade, founded in 1891 or SOFINA, Société Financière de Transports et d' Entreprises Industrielles, that since
1905 , began to invest in several countries, such as Spain and in 1913 it became the majority stockholder of CRGE, by subscribing 96,000 shares. SOFINA's presence in Portuguese companies extended to the Sociedade Energia Eléctrica, founded in Porto in 1908. Another example of electricity companies acting in Portugal is given by AEG, which by 1910 had installed in the country several hydro-electrical and thermal power stations, e.g. the stations in Évora, Chaves, Régua, Lamego and Angra do Heroísmo, which produced energy for lighting and industrial consumption. Their action extended to the construction of electrical power stations linked to tramways in the country's main cities - Lisbon, Porto and Coimbra.

In 1917, the country had 39 electrical power stations - 12 hydro-electrical, 21 thermal and 6 mixed-type. Their combined power output of $13,136 \mathrm{~kW}$, with an average of $336.8 \mathrm{~kW}$ per station and an average consumption of $1.9 \mathrm{~kW}$ per 100 inhabitants. The consumption data in Portugal, in the first quarter of the 20th century, shows a pronounced distance between the Portuguese market (covering only $15 \%$ of the country's municipalities) and the consumption levels in the main European countries. Interest in hydro-electricity, which had begun at the end of the 19th century, saw an increase during the First World War due to the shortage of imported coal, which would be reflected in the activity of thermal power stations - especially those belonging to the big companies in Lisbon and Porto, namely CRGE and Sociedade de Energia Eléctrica (Matos, Sampaio 2016). 
The presence of electrical enterprises such as Siemens in Portugal dates back to 1876 when the company installed a furnace with heat recovery system in the Real Fábrica de Vidros da Marinha (a glass factory). In the ensuing years, Siemens supplied machines and other equipment to several Portuguese companies, including those needed for the installation of the tramways of Oporto, which began working in 1895 , and by the tramways of Lisbon, which started operating in 1901. Initially, acquisitions were made through Madrid, where the German group Siemens founded, in 1899, the Compañía Anónima Española de Electricidad, but in 1905, a new branch was created in Lisbon, under the name Companhia Portuguesa de Electricidade Siemens-Schuckert Werke, Lda, with an office in the city of Oporto (Alves 2005: $55)$. The opening of this branch was a sign of the development, which the Portuguese electricity market had undergone since the end of the 19th century.

Another enterprise with interest in the Portuguese market ASEA - Allmänna Svenska Elektriska Aktiebolaget, a Swedish enterprise responsible for the introduction of the electrical motor. Jonas Wenströn conceived a new motor, after visiting the International Exhibition in 1881 (Barnevick 1983: 12), and in 1894, he patented his invention and in the letter of presentation he wrote:

My invention relates to dynamo electric machines of that particular cases in which the armature, field magnet and the conductors thereon are all stationary, the rotary part being a body of iron called the "Keeper" [...]. My Invention consists in the construction whereby I am enable to operate a machine of this description without eddy currents with construction, consist of an armature having a continuous surface facing the keeper. (United States Patent Office, 1894: 1)

ASEA launched, in 1924, a new engine that incorporates the characteristics of the induction motors produced until then by the Swedish company. The new engine was more appropriate for textile industry, carpentry, mechanical metalworking and had the advantage of shortening the length of the free shaft between bearings, thus reducing the risk of fouling the area between the stator and the rotor (ASEA Journal, 1924: 12). These motors were designed to be used in the mines and had a housing, specially built for the collector rings. They could have different forms of joining to the machine tool: either direct or by transmission belt and with or without third bearing. When this engine was conceived and designed, it was intended to maximize the use of the motor, exploring options that had been extensively studied at the time introducing two important innovations: issues associated with bearings and the introduction of a new ventilation system. In Portugal, Jayme da Costa enterprise will be the branch of ASEA until 1960, only by trading its products.

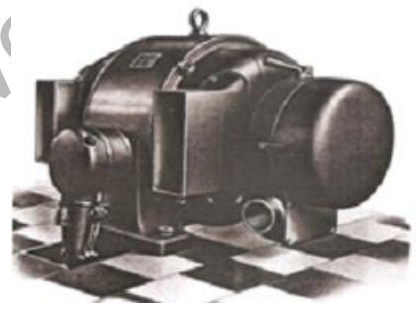

Fig. 1: Fig. 1 - 3-phase Motor Type MK - B, de cage, or squirrel. Source: ASEA - Journal, 1924 , p. 12.

The technological evolution and improvements introduced in electric motors were constant, driven by the growth of cities, their lighting networks and the pressure for technological solutions. The emerging sectors were requesting, namely, more power and more speed for their machine. The introduction and improvement of the engines are associated with the requirements of higher mechanical yields, which industrial development needed at each stage. Portugal started the manufacture of electric motors in large quantities in 1946 when ACEC, EFA and CUF joined to develop a business project that in 1960 took the name of 
EFACEC. The technologic input of the Belgium partner ACEC was crucial to the development of the business project and made the technological transfer possible.

EFACEC origins go back to the year 1915, with the setting up of a small factory called A Moderna - Sociedade de Serração Mecânica, which would later become Electro-Moderna Lda, located in the city of Porto. Born in a context of a shortage of raw materials and highly expensive imported equipment, such as electrical engines, this small, workshop based enterprise sought to cater to the market as far as its technical capacities could go. To that end, the company set up a Secção Metalúrgica (Metallurgical Division) for repairing electrical machinery. Also, making good use of its managers' and technicians' knowledge, it sought to find solutions for the lack of imported equipment - by repairing machines, recycling materials and finally manufacturing electrical engines(EFACEC 2009).

\section{The electric Motor and the technological progress}

The term electric motor is attributed to the object that produces mechanical energy regardless of the type of energy that powers it: thermal, hydraulic, gas, wind or solar. (Larousse 1971) The electrical current activates other machine tool, transforming electric energy into mechanic energy.

Electric motors are used in a variety of industrial and domestic situations, and they can be found in the interior of ventilators, extracting bombs, home appliances, or attached to toolmachines, etc. They can be fed directly by a portable battery, by continuous current or alternated current, and this can be produced locally or originate from a central located several miles away. (Herléa 1985).

The installation of a motor depends on its effective power that will be proportional to the set of operating machines and devices that it is going to activate. That has not always been taken into consideration by investors because the relation between power and the installation of machinery is not the main concern when deciding to invest. This is a reason why, in the Portuguese industry, hydraulic motors became less important. Thermal motors were better integrated and that was a crucial factor for the establishment of the steam machine as the main industrial motor (Santos 2000). In the specific case of the district of Oporto, one can verify an increase in the number of steam machines between 1890 and 1910: starting with 37 machines installed with a power of $1.627 \mathrm{hp}$ rising to 104 steam machines with a power of $13043 \mathrm{hp}$. Most of them were bought in England and France, the main exporters to the Portuguese market (Santos 2000, p. 278).

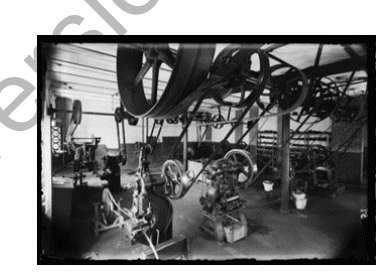

Fig. 2 - Machines-tools using shafts and belts. Use of hydro or thermal energy. Source: Centro Português de Fotografia /DGLAB/MC, PT/CPF/ALV/003914.

Initially, the use of thermal or hydraulic motors demanded that shafts and belts connecting the motor to the transmission that in turn was connected to each one of the operating machines made mechanical transmissions. This process demanded an initial preparation of the motor (the process of heating), as well as an energy transmission path that extended over several sections and spaces, in which importantly losses were registered, especially, if the belts were poorly installed or were deteriorated, forcing high maintenance costs. On the other hand, with electric motors, even if there were losses in the dynamo (generator), we have less energetic waste because the electricity has a regular supply; however, in the early years it was normal to have failures, in 
particular at summer, when the Portuguese rivers have a low flow rate. The electric motor had a regular mechanic activation, mainly behind its wheel, what produce also an inert energy use in the industrial process. Its introduction, joined with the introduction of tool machines allowed for each one to be autonomous, while a group of operating machines made the transmission of power with steam or hydraulic motor. The changing of the transmission networks to an individual transmission optimized the space inside the factory and the productive capacity without the need for additional investments. It even reduced costs, not requiring lifting mechanisms and heavy components because the individual transmission allowed the establishment of a direct connection between the tool and the piece. Furthermore, the installation of an electric motor per machine had the advantage of reducing accidents, giving the operator the possibility to directly regulate and interact with the machine. Besides, it was no longer subject to the rotation of axle lines or transmission belts that extended through the workspace. Progressively, the tendency was for each machine to be conjoined with a motor, that was turned on and off according to the needs of the operator. In regarding this, the engineer responsible for the $1^{\text {a }}$ Circunscrição Industrial (1st Industrial circumscription) services stated that,

Os motores eléctricos pelo pouco espaço que ocupam, facilidade de montagem e funcionamento com reduzida mão-de-obra para a condução, comodidade e economia resultantes do emprego de motores individuais para cada máquina ferramenta ou grupo de máquinas ferramenta, etc., estão a ter uma crescente aplicação". (Viegas, 1924: 17-18) ${ }^{1}$

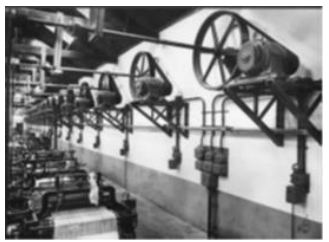

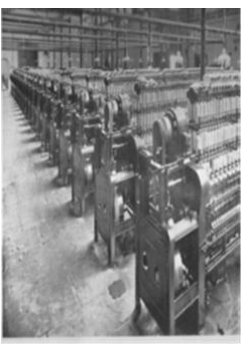

Fig. 3 and 4 - Portuguese Industrial units with electrical motors in different phases of its evolution. Source: Enterprise Archive: Jayme da Costa SA.

In Oporto and Lisbon, in the decade of 1920 , electricity was already used in several factories associated with toolmachines, mostly in electric motors of small power. For a traditionally disperse industry, set in workshops and domestic units, the introduction of electric motors must have greatly contributed to the progress of big industrial units, as well as to the increase of productivity and to give a breath of fresh air to the domestic industry (Matos, Mendes and Cruz 2004: 216).

There are several types of electric motors, its manufacture and characteristics must be analysed from distinct processes: the scientific and technological progress of the 19th and 20th centuries that allowed for industrial development with the use new energy sources (first the steam and later electricity), and improved the routes of technological exchange between northern and southern Europe. Also important was the search for new materials and new metals that modified production procedures, expanded markets and means of consuming.

Electric motors started being manufactured in the 19th century, but big scale production depended on electric generators and electricity distribution networks, structures that would be developed in the beginning of the 20th century (Costa 1945: 5).

Through the 20th century, the electric 
equipment companies dedicated themselves to manufacturing industrial motors. The most common was a cage or squirrel motor. It was used in various machines, both in industrial and domestic sectors as, for instance, the first washing machines.

From the first motors until the current ones, scientific and technological development, namely electrical and mechanical calculation, the model and production of new construction materials and the evolution of manufacturing processes, allowed for the perfecting of the characteristics of the electric motor. Therefore, since the beginning of the 20th century until the 1980 s these changes, among others, contributed to a reduction of motors weight and size to less than half. Gradually, a more resistant and armoured frame, other metallic alloys and different ventilation systems were developed as applications became more diversified. This technological evolution is essentially due to the production of lighter metals, the replacement of forged iron by aluminium in the armour, the development of new isolating materials that can stand higher temperatures and a progressive adaption of the motor's power and dimension.

Hydraulic and thermal motors were under the control of Circunscrições Industriais (Industrial Circumscriptions), but the inspection of the electric motors belonged to the Repartição das Indústrias Eléctricas (Division of Electrical Industries). However, the surveillance was reduced because they were considered "secondary" motors for (re)transforming steam or hydraulic energy. This way of interpreting the electric motor caused a lack of information regarding its operation, and consequently, one has now less knowledge of the installed power and the progressive functioning entry. Its installation and maintenance became a business for small companies that placed new steering wheels, performed its rewinding, did cleanings, changed oils and replaced parts.

The data collected until now suggests an increase in the entry of foreign electric machines in Portugal, after the First World War. This led the government to change the importing rates, raising tax deductions on this type of material. Its systematic entry, in the 1920 s, is due to the start of operation of the first hydroelectric plants allowing the production of cheaper energy in larger quantities and making possible the progressive entry of electricity in public lighting and in industrial activities.

\section{The impact of electric motor}

The electric motor brought several changes to the manufactures' space, which gained more linearity, new places for the rheostats, the feeding panels, and the energy cut appears, as well as for the switches, light bulbs, and outlets. Like other countries, in Portugal, since 192030 we found in the photographs of the industrial units that motors were on all the devices and the workspace became more rationalized and gave manufacturers flexibility in the design of the buildings and in the arrangement of the machinery (Devine 1983: 364).

The process of electrification and the introduction of the electric motor into the factory brought changes that permitted not only to rationalize the flux between worker and machine tool but also the operational circuit between different machines and operations. The machinery aligned in the operational chain is now reinforced by the electric motor that shapes the entire production process and each operator gains prominence by controlling its own machine and electric connection, obtaining a larger responsibility and articulating himself with an indispensable new member of the factory: the electrician. Gradually he became more qualified after receiving specific education in Industrial Schools. In these, since 1925, there were taught specific courses and starting in 1948 Portuguese Industrial School started teaching courses for electrician assembler. The diploma was a real innovation, because it introduced a 
preparatory cycle in technical education, extending the scope of training, vocational guidance, and thus functioning as a means to the rise of the popular classes (Stoer, Stoleroff and Correia 1998: 9).

The motors were initially made of forged iron, had big dimensions and were heavy. Its components were joined by screws of different sizes and had electric wires covered in cotton, different openings, handles, and bases. The use of aluminium, bakelite and other plastics improve the object and its use. The production of motors altered the manufacturing processes and the technical characteristics of the motors. These became lighter, with simpler armours, and joints between its components. Initially, the ventilation systems were not diversified; the most used one being the axle that had a direct impact in the heating motor, which forced the operator to place his hand on the armour to check if it could work longer. With technical progress, different ventilation systems were implemented and the motor was able to stand higher temperatures and work for longer hours. The copper wire that used to be layered in cotton was now covered in a plastic sleeve.

\section{Conclusion}

Today, the motor is still used in the same contexts as initially: in agriculture, activating bomb-motors and other agriculture machines, in the industry, it is still joined with many machines or as a generator of mechanic force. Its characteristics are now more clear and versatile; its manufacture was standardized as result of the organization and regulation of the markets.

\section{Bibliographical References}

ASEA Journal. Anos 1924-1928. Västerås -Sweden.

Barvenik, Percy. (1983) Electrifying experience: A brief account of the first century of the ASEA group of Sweden 1883-1983, with a special postscript on the future. Sweden: ASEA.
Centro Português de Fotografia/DGLAB/SEC, PT/CPF/ALV/003914.

Costa, Jayme da. (1945). Jayme da Costa. Porto.

Devine, W.D (1983). From shafts to wires: Historical perspective on electrification. Journal of Economic History. Cambridge: Cambridge University Press.

Efacec. (2009) EFACEC 60 anos: 1948-2008. S. Mamede de Infesta: EFACEC.

Herléa, Alexandre. (1985) Les Moteurs. Paris: Presses Universitaires de France.

Madureira, Nuno Luís and MATOS, Ana Cardoso de. (2004) A tecnologia. In Pedro Lains and Álvaro Ferreira da Silva (Orgs.), História Económica de Portugal 1700-2000, vol. II - o século XIX (pp. 189-218). Lisboa: Imprensa de Ciências Sociais.

Madureira, Nuno Luís, and Matos, Ana Cardoso de. (2004) A tecnologia. In Pedro Lains and Álvaro Ferreira da Silva (Orgs.), História Económica de Portugal 1700-2000, vol. II - o século XIX (pp. 189-218).Lisboa: Imprensa de Ciências Sociais.

Matos, Ana Cardoso and SAMPAIO, ML. (2016) The Branches of large electricity Companies in Portugal. From trade to the transfer and adaptation of technology (20th century). in Mondes Electriques. Bern: Peter Lang.

Matos, Ana Cardoso de. (2010) Electricidade, produção, distribuição e consumo. In Dicionário da História da I república e do republicanismo. Vol. I: A-E (pp. 1104-1111). Lisboa: Assembleia da República.

Matos, Ana Cardoso de (Coord.). MENDES, Fátima et al (2003) O Porto e a electricidade. Lisboa: EDP/ Museu da Electricidade.

Santos, Maciel. (2000) Os capitais metalúrgicos em Portugal 1840-1930. Tese de Doutoramento, vol. I e II. Faculdade de Letras da Universidade do Porto.

Stoer, Stephen R.; Stoleroff, Alan; Correia; José. (1990) O novo Vocacionalismo na Política Educativa em Portugal e a Reconstrução da Lógica da Acumulação. In Revista Crítica de Ciências Sociais, 29, Fev. de 1990, 11-53.

UNITED STATES PATENT OFFICE. (1894) Jonas Westron, of Örebro, Sweden, Dynamo-Electric Machine, p. 1, Feb. Signification Forming part of Letters Patent $n^{\circ} 515,386$ - Letter Jonas Wenström, Dynamo Electric. Machine, patented February 27, 1894 http://patentimages.storage.googleapis.com/ pdfs/US515386.pdf

Viegas, José dos Santos Salvador. (1926) Relatório dos serviços da $1 .^{a}$ Circunscrição industrial, ano 1923. Boletim do Trabalho Industrial, 128.

Wenström, Jonas. (1894) Dynamo Electric Machine. Patented 27th February. Specification forming part of letters patent $n^{\circ} 515.386$. Available: http://patentimages.storage.googleapis.com/ pdfs/US515386.pdf. 2015 -06-02 
${ }^{1}$ Translation: "the small space occupied, the facility of assembly, the operation of reduced labour, convenience and economy resultant from the use of individual motors to each machine-tool or group of machine-tools are reasons why electric motors are having a growing application" (Viegas, 1924: 17-18). 